\title{
Colocalization of GABA, Glycine, and their Receptors at Synapses in the Rat Spinal Cord
}

\author{
A. J. Todd, ${ }^{1}$ C. Watt, ${ }^{1}$ R. C. Spike, ${ }^{1}$ and W. Sieghart ${ }^{2}$ \\ 1Laboratory of Human Anatomy, Institute of Biomedical and Life Sciences, University of Glasgow, Glasgow G12 8QQ, \\ United Kingdom, and 2University Clinic for Psychiatry, Department of Biochemical Psychiatry, A-1090 Vienna, Austria
}

To determine whether GABA and glycine can act as cotransmitters at synapses in the rat spinal cord, we have compared the ultrastructural distribution of $\mathrm{GABA}_{\mathrm{A}}$-receptor $\beta_{3}$ subunit with that of the glycine receptor-associated protein gephyrin and combined this with postembedding detection of GABA and glycine. We also used a dual-immunofluorescence method to confirm that gephyrin was associated with the glycine-receptor $\alpha_{1}$ subunit throughout the cord. GABA $\beta_{3}$-subunit immunoreactivity was restricted primarily to synapses, and at a majority of these synapses the presynaptic axon was GABAimmunoreactive. Many synapses showed both $\mathrm{GABA}_{\mathrm{A}} \beta_{3}$ and gephyrin immunoreactivity, and at most of these synapses GABA and glycine were enriched in the presynaptic axon. These results strongly support the idea that cotransmission by GABA and glycine occurs in the spinal cord.

Key words: $G A B A_{A}$ receptor; glycine receptor; gephyrin; transmitter colocalization; immunocytochemistry; electron microscopy
GABA and glycine, the major inhibitory neurotransmitters in the spinal cord, act on ligand-gated chloride channels: $\mathrm{GABA}_{\mathrm{A}}$ and glycine receptors. The glycine receptor consists of $\alpha$ (ligandbinding) and $\beta$ (structural) subunits together with gephyrin, a peripheral membrane protein that anchors the receptors at synapses by linking them to underlying microtubules (Kirsch et al., $1991,1993)$. The main adult form of the $\alpha$ subunit $\left(\alpha_{1}\right)$ apparently is restricted to glycinergic synapses; however, the $\beta$ subunit is found in many areas in which glycinergic transmission is believed not to occur (Malosio et al., 1991; Sato et al., 1991; Kirsch and Betz, 1993). The distribution of gephyrin is complex: in certain regions, such as spinal ventral horn, it is colocalized with the glycine-receptor $\alpha_{1}$ subunit (Triller et al., 1987), whereas in many parts of the central nervous system it occurs without the $\alpha_{1}$ subunit (Kirsch and Betz, 1993; Sassoè-Pognetto et al., 1995). $\mathrm{GABA}_{\mathrm{A}}$-receptor subunits have been divided based on sequence homology into four main classes- $\alpha, \beta, \gamma$, and $\delta$-and it is believed that naturally occurring $\mathrm{GABA}_{\mathrm{A}}$ receptors contain $\alpha, \beta$, and $\gamma$ subunits (Sigel et al., 1990; Verdoorn et al., 1990; Sieghart, 1992; Amin and Weiss, 1993). At least four different $\alpha$ subunits are present in rat spinal cord; however, in the case of $\beta$ and $\gamma$ subunits, a single type $\left(\beta_{3}, \gamma_{2}\right)$ is predominant and is expressed by most, if not all, spinal neurons (Persohn et al., 1991, 1992; Wisden et al., 1991; Ma et al., 1993).

Many spinal neurons are inhibited by GABA and glycine (Curtis et al., 1968), and certain types of evoked inhibition can be blocked by both strychnine and bicuculline (Game and Lodge, 1975; Cullheim and Kellerth, 1981; Rudomin et al., 1990; Schneider and Fyffe, 1992; Yoshimura and Nishi, 1995), which indicates that inhibition is mediated through $\mathrm{GABA}_{\mathrm{A}}$ and glycine recep-

Received Aug. 9, 1995; revised Oct. 16, 1995; accepted Oct. 24, 1995.

This work was supported by grants from the Wellcome Trust, the Robertson Trust, and the Royal Society. We thank Dr. D. V. Pow for donating antisera to GABA and glycine, Prof. H. Betz and Dr. J. Kirsch for the gift of monoclonal antibody $2 b$, and Drs. D. J. Maxwell and S. A. S. Shehab for helpful discussions.

Correspondence should be addressed to Dr. A. Todd, Laboratory of Human Anatomy, University of Glasgow, Glasgow G12 8QQ, UK.

Copyright $(\mathcal{C} 1996$ Society for Neuroscience $0270-6474 / 96 / 160974-09 \$ 05.00 / 0$ tors. Because many boutons in the spinal cord contain both GABA and glycine (Örnung et al., 1994; Taal and Holstege, 1994; Todd et al., 1995), these compounds may act as cotransmitters. However, the presence of GABA and glycine in axon terminals does not prove that they both function as transmitters at synapses formed by these axons. For example, GABA and glycine coexist in cerebellar Golgi cells (Ottersen et al., 1988), but there is doubt that glycine functions as a transmitter in this situation (Luque et al., 1995). In addition, the two compounds coexist at axo-axonic synapses in spinal cord (Todd et al., 1995), although glycine is believed not to be involved in presynaptic inhibition.

To examine the possibility that GABA and glycine act as cotransmitters, we used an antibody directed against $\mathrm{GABA}_{\mathrm{A}^{-}}$ receptor $\beta_{3}$ subunit and a monoclonal antibody against gephyrin (which we found to be colocalized with the glycine-receptor $\alpha_{1}$ subunit throughout the cord) to search for ultrastructural evidence that $\mathrm{GABA}_{\mathrm{A}}$ and glycine receptors coexist at synapses in rat spinal cord. We also combined this approach with postembedding immunocytochemistry to look for the presence of GABA and glycine at such synapses.

\section{MATERIALS AND METHODS}

Preparation of antibody against $G A B A_{A^{-}}$-receptor $\beta_{3}$ subunit

The $\beta_{3}$ antibody was raised in rabbit against a fusion protein consisting of maltose-binding protein and amino acids $345-408$ of the rat $\beta_{3}$ subunit, part of the large intracellular loop between putative transmembrane domains M3 and M4 (Vector pmal C2; New England Biolabs, Beverly, MA). Antibodies were isolated by chromatography on a fusion protein consisting of glutathione S-transferase, amino acids 345-408 of the $\beta_{3}$ subunit, and scven histidincs (Vcctor pGEX-4T-1; Pharmacia, Vicnna, Austria). The procedure was otherwise identical to that described previously (Mossier et al., 1994; Tögel et al., 1994). The antibody identified two proteins with $M_{\mathrm{r}}$ values of 53 and $56 \mathrm{kDa}$ in Western blots of affinity-purified $\mathrm{GABA}_{\mathrm{A}}$ receptors. In addition, in preliminary experiments this antibody was found to precipitate recombinant $\mathrm{GABA}_{\mathrm{A}}$ receptors efficiently from extracts of human embryonic kidney cells transfected with $\alpha_{1} \beta_{3} \gamma_{2}$ subunits. The antibody did not precipitate $\alpha_{1} \beta_{1} \gamma_{2}$ receptors, and the amount of $\alpha_{1} \beta_{2} \gamma_{2}$ receptor precipitated was $\sim 6 \%$ of that precipitated from extracts of $\alpha_{1} \beta_{3} \gamma_{2}$-transfected cells (K. Fuchs and W. Sieghart, unpublished data). 


\section{Immunocytochemistry}

Tissue preparation. Eight albino Swiss rats (either sex; 220-390 gm) were anesthetized deeply and fixed by vascular perfusion. For light-microscopic detection of $\mathrm{GABA}_{\mathrm{A}}$-receptor $\beta_{3}$ subunit, three rats were perfused with $4 \%$ formaldehyde. For electron-microscopic detection of the $\beta_{3}$ subunit, alone or in combination with gephyrin, two rats were perfused with $4 \%$ formaldehyde $(0.05 \%$ glutaraldehyde and three rats were perfused with $1 \%$ formaldehyde $/ 1 \%$ glutaraldehyde. Lumbar spinal cord segments were removed, stored for $2-4 \mathrm{hr}$ in the same fixative, and then cut into $60 \mu \mathrm{m}$ transverse sections on a Vibratome. Detection of glycine-receptor $\alpha_{1}$ subunit and gephyrin was performed on $7 \mu \mathrm{m}$ cryostat sections of lumbar spinal cord obtained from an additional two rats (male; 350 and $380 \mathrm{gm}$ ) that had been decapitated.

Pre-embedding immunocytochemistry. For light-microscopic detection

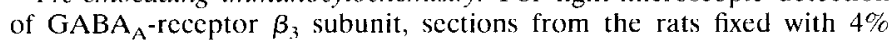
formaldehyde were incubated overnight in $\beta_{3}$ antibody $(0.11-0.9 \mu \mathrm{g} / \mathrm{ml})$ and reacted by the avidin-biotin complex $(A B C)$ method with nickelintensified diaminobenzidine (DAB) as chromogen. For electron microscopy of $\beta_{3}$ immunoreactivity, sections from the three rats perfused with $1 \%$ formaldehyde $1 \%$ glutaraldehyde were incubated overnight in $\beta_{3}$ antibody $(0.9 \mu \mathrm{g} / \mathrm{ml})$, reacted by the $\mathrm{ABC}$ method with $\mathrm{DAB}$ as chromogen. post-fixed in osmium tetroxide, dehydrated, and flat-embedded in Durcupan. From each rat, ultrathin sections were cut from blocks that included superficial dorsal horn (laminae I-III), deep dorsal horn (laminae IV-V), and part of the ventral horn (including lamina IX).

For simultaneous ultrastructural visualization of $\beta_{3}$ and gephyrin immunoreactivity, double labeling was performed using the method of Chan et al. (1990). Vibratome sections from four of the rats perfused with formaldehyde/glutaraldehyde fixatives were incubated overnight in a mixture of $\beta_{3}$ antibody $(0.9 \mu \mathrm{g} / \mathrm{ml})$ and antibody 7a (diluted 1:5000; Boehringer Mannheim, Mannheim, Germany), followed by biotinylated antirabbit $\operatorname{IgG}(1: 200$; Vector, Peterborough, UK) and anti-mouse IgG coated with $1 \mathrm{~nm}$ gold particles (1:200; British Biocell, Cardiff, UK). The gold particles (rcpresenting gephyrin immunoreactivity) were intensified with silver (IntenSE kit, Amersham, Arlington Heights, IL), and $\beta_{3}$ immunoreactivity then was revealed with the $\mathrm{ABC}$ technique and $\mathrm{DAB}$. The sections were osmicated, dehydrated, and embedded in Durcupan. Ultrathin sections were obtained from superficial and deep parts of the dorsal horn and from the ventral horn.

All absorption control for $\mathrm{GABA}_{\Lambda^{-}}$-receptor $\boldsymbol{\beta}_{3}$-subunit immunostaining was performed by incubating sections of spinal cord fixed with $1 \%$ glutaraldehyde $/ \%$ formaldehyde in $\beta_{3}$ antibody $(0.9 \mu \mathrm{g} / \mathrm{ml})$ to which fusion protein $(1 \mu \mathrm{g} / \mathrm{ml}$ glutathione S-transferase, amino acids $345-408$ of the $\beta_{3}$ subunit, and seven histidines) had been added $2 \mathrm{hr}$ previously. This abolished immunostaining. Controls for the duallabeling pre-embedding reaction involved omitting one of the two primary antibodies.

Postembedding immunogold method. To examine the relationship between the GABA -receptor $\beta_{3}$ subunit and GABA, ribbons of ultrathin sections were cut from material that had been reacted with the $\beta_{3}$ antibody by the pre embedding method (see above). From each of the three animals, ultrathin sections from the superficial and deep parts of the dorsal horn and from the ventral horn were studied. In each case, a single ultrathin (reference) section was mounted onto a copper-Inesh grid and stained with lead citrate, and the two succeeding sections were collected onto a Formvar-coated, single-slot nickel grid and reacted with antiserum to GABA by a modification of the method of Holstege (1991). The grid was incubated for $1 \mathrm{hr}$ with PBS (containing $0.1 \%$ Triton $\mathrm{X}-100$ and $1 \%$ bovine serum albumin) and overnight with the same solution containing antiserum to GABA (diluted 1:2000) (Pow and Crook, 1993). Then it was rinsed and incubated with goat anti-rabbit IgG coated with 10 $\mathrm{nm}$ gold particles (diluted 1:25; British Biocell). From each of the nine reference sections, $10 \beta_{3}$-immunoreactive synapses and 5 asymmetrical synapses were selected, and these then were located and photographed on the two corresponding serial sections reacted with $G \Lambda B \Lambda$ antiserum The background level of gold-particle density was taken as the average density over the axons presynaptic at the asymmetrical synapses (which were presumed not to be GABAergic). Axons presynaptic at $\beta_{3^{-}}$immunoreactive synapses were counted as GABA-immunoreactive if the density of gold particles over them exceeded the background level by at least fourfold on both sections.

Detection of GABA- and glycine-like immunoreactivity was performed on material that had been reacted with antibodies to both the $\mathrm{GABA}_{\mathrm{A}}$-receptor $\beta_{3}$ subunit and gephyrin (see above) from two of the rats fixed with $1 \%$ formaldehyde/1\% glutaraldehyde. From each rat, one block of deep dorsal horn and one block of ventral horn were used. Ribbons of five ultrathin sections were cut from these blocks and mounted onto grids in serial order. The third (reference) section was mounted onto a copper-mesh grid and stained with lead citrate, and the other sections were collected onto Formvar-coated, single-slot nickel grids. The grid with the first two sections of the ribbon was reacted with antiserum to GABA as described above, and the grid with the fourth and fifth sections was reacted in the same way, but with antiserum to glycine (1:1000) (Pow and Crook, 1993). Forty synapses showing both $\beta_{3}$ and gephyrin immunoreactivity were selected from the reference sections (10 from each block); they then were examined and photographed on both of the sections reacted with GABA antiserum, and both sections reacted with glycine antiscrum. GABA immunoreactivity in the presynaptic axons was defined as above, whereas axons were considered to be glycine-immunoreactive if the gold-particle density exceeded the background level (over 5 axons that formed asymmetrical synapses on the same grid) by at least twofold on both sections. We have found that this value provides a suitable cut-off point for distin guishing axonal boutons in the spinal cord that are enriched with glycine from those that are not (Todd et al., 1995). We have shown previously that immunostaining with the GABA and glycine antisera can be blocked selectively by pretreatment with a conjugate of the corresponding amino acid but not with a conjugate of the other amino acid (see Fig. 5 of Todd et al., 1995). The antibodies also have been applied to test sections and found to show no cross-reactivity with the inappropriate amino acid (glycine or GABA) or with a varicty of other amino acids, including taurine, glutamate, glutamine, or aspartate (Pow, 1994; Pow and Robinson, 1994). The GABA and glycine antisera were donated by Dr. D. V. Pow (University of Queensland).

Immunofluorescent detection of monoclonal antibodies $2 b$ and $7 a$. To determine the relationship between gephyrin and the glycine-receptor $\alpha_{1}$ subunit, a modification of the method of Triller et al. (1987) was used. Fifteen unfixed cryostat sections of spinal cord taken from two rats were mounted onto gelatinized slides, incubated in monoclonal antibody 2 b (diluted 1:50 or 1:100; donated by $\mathrm{H}$. Betz, Max Planck Institute for Brain Research, Frankfurt, Germany), rinsed, and fixed briefly in $4 \%$ formaldehyde. They were treated with a Fab' fragment of goat anti-mouse IgG conjugated to lissamine rhodamine (1:100; Jackson Immunoresearch, West Grove, PA), and then with unconjugated Fab' fragment of goat anti-mouse IgG (1:20; Jackson) in an attempt to saturate binding to monoclonal antibody $2 \mathrm{~b}$. They then were incubated in monoclonal antibody 7 a $(1: 100)$ and, finally, with horse anti-mouse IgG conjugated to fluorescein (1:50; Vector). Sections were viewed with conventional epifluorescence and with a Bio-Rad MRC 1024 confocal laser scanning microscope equipped with a krypton-argon laser (Hercules, CA). For confocal microscopy, sections were scanned sequentially with the 488 and $568 \mathrm{~nm}$ laser lines to prevent bleedthrough fluorescence. Control sections were treated in the same way, except that one of the primary antibodies was omitted, and additional sections were incubated only with antibody $2 b$ or $7 \mathrm{a}$ and the corresponding fluorescent secondary antibody.

\section{RESULTS}

\section{GABA $_{A}$-receptor $\beta_{3}$-subunit immunoreactivity}

In sections of lumbar spinal cord incubated with antibody to GABA $A_{A}$-receptor $\beta_{3}$ subunit, immunoreactivity was present in all parts of the spinal gray matter but varied in intensity in different areas (Fig. $1 A$ ). Immunostaining was most dense in laminae I and II and was present at moderate levels in a band including laminae III and IV, the medial aspect of the deep dorsal horn, and extending to the area around the central canal, as well as in the motor nuclei of the ventral horn. In the lateral part of the deep dorsal horn and the remainder of the ventral horn, immunostaining was less dense. At high magnification, punctate immunoreactivity was found in all parts of the gray matter, but a few immunoreactive cell bodies were present in laminae III and IV (Fig. $1 B$ ), and strongly immunoreactive dendrites were common in laminae II and III. In some cases, dendrites could be followed from the immunoreactive cell bodies. Elsewhere in the spinal gray matter, extensive staining of dendritic shafts was extremely rare, 

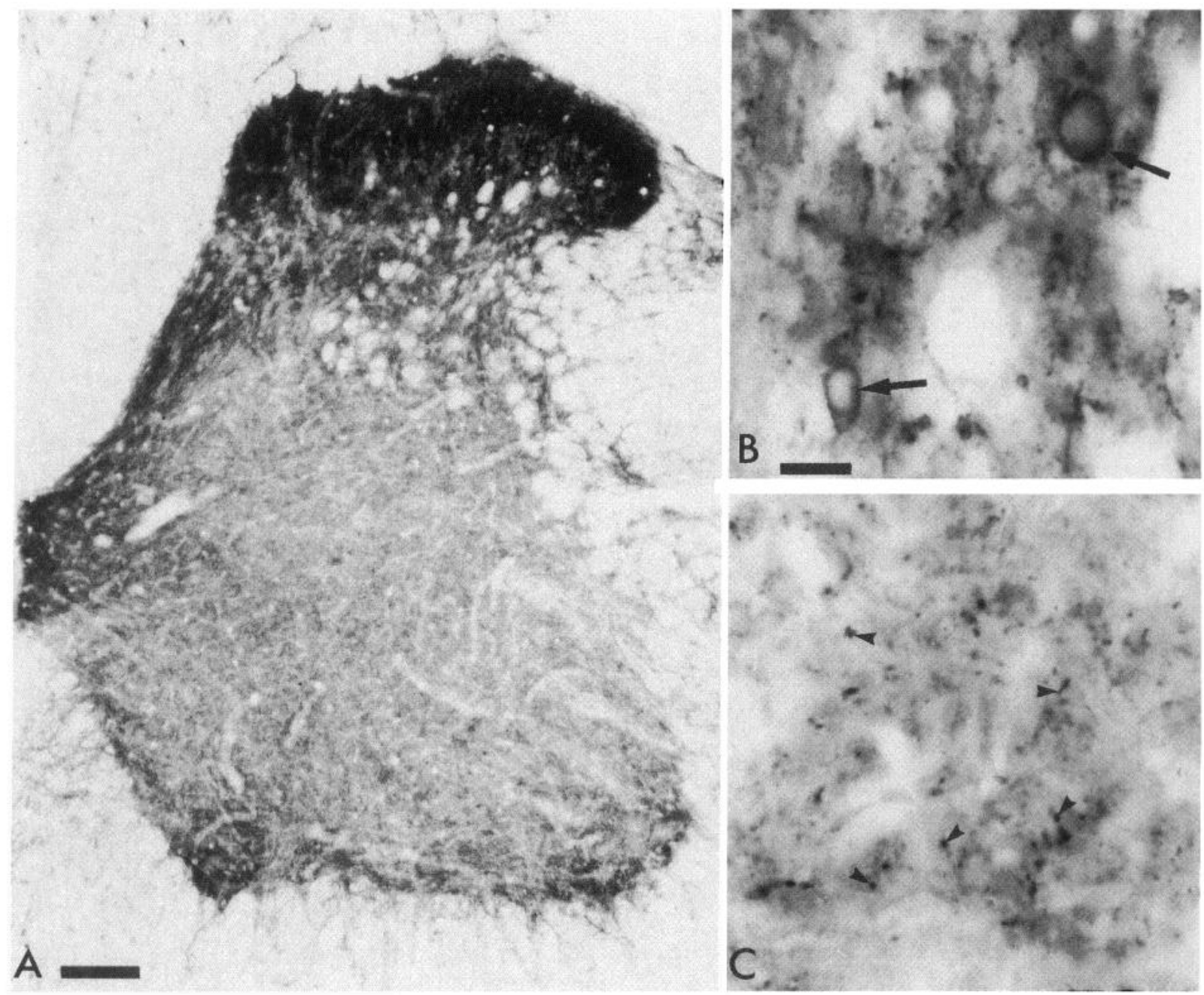

Figure 1. The light-microscopic appearance of immunostaining with antibody to GABA $\mathrm{A}_{\mathrm{A}}$-receptor $\beta_{3}$ subunit in the spinal cord. $A$, Immunoreactivity is present throughout the gray matter but is most dense in the superficial dorsal horn and moderate in the medial part of the deep dorsal horn, the area around the central canal, and in the motor nuclei of the ventral horn. $B$, Part of lamina III at high magnification. Two immunoreactive cell bodies (arrows) are visible. $C$, Punctate immunostaining in lamina IX. Some of the puncta are indicated with arrowheads. Scale bars: $A, 100 \mu \mathrm{m} ; B, C, 10 \mu \mathrm{m}$.

and the immunoreactivity was almost exclusively punctate (Fig. 1C).

With electron microscopy, most of the immunoreactive puncta were found to correspond to synapses. Reaction product was present on the internal aspect of the plasma membrane of the postsynaptic element and showed limited extension into the adjacent cytoplasm (Figs. 2-4). There usually was little spread of reaction product away from the active site, so nearby synapses were unlabeled (Figs. 2, 4). As suggested from light-microscopic observations, some cell bodies and many dendrites in laminae II-IV of the dorsal horn showed more extensive filling with reaction product.

Because immunostaining with this antibody tolerated fixation with $1 \%$ glutaraldehyde, we were able to carry out postembedding immunocytochemistry with antiserum to GABA on ultrathin sections, to determine whether the axons presynaptic at $\beta_{3}$ immunoreactive synapses were GABAergic. Ninety randomly selected $\beta_{3}$-immunoreactive synapses were examined (10 in the ventral horn and 10 in both superficial and deep parts of the dorsal horn, each in 3 rats), and at 84 of these (93\%) the presynaptic element was GABA-immunoreactive (Fig. 2).

\section{GABA $A_{A}$-receptor $\beta_{3}$-subunit and gephyrin immunoreactivity}

To study the relationship between $\mathrm{GABA}_{\mathrm{A}}$ and glycine receptors at the ultrastructural level, we used a double-label pre-embedding immunocytochemical technique to reveal $\mathrm{GABA}_{\mathrm{A}}$-receptor $\beta_{3}$ subunit with the $\mathrm{ABC}$ method; silver-intensified immunogold was used to reveal gephyrin. In ultrathin sections cut from this material, the two types of reaction product could be distinguished easily (Figs. 3, 4). Each type showed a similar distribution to that seen in sections processed with the corresponding antibody alone, and omission of either primary antibody abolished the associated type of immunostaining. In each area examined (the ventral horn and superficial and deep parts of the dorsal horn), many synapses possessed only silver particles (corresponding to gephyrin) or $\mathrm{DAB}$ (corresponding to $\mathrm{GABA}_{\mathrm{A}}$-receptor $\beta_{3}$ subunit), whereas other synapses were double-labeled (Figs. 3, 4). At double-labeled synapses, the two types of reaction product could be either intermingled (Figs. $3 A, 4 A$ ) or partially or completely segregated. In the latter case, the reaction products often were side-by-side, but a common arrangement was for the DAB to be concentrated at 


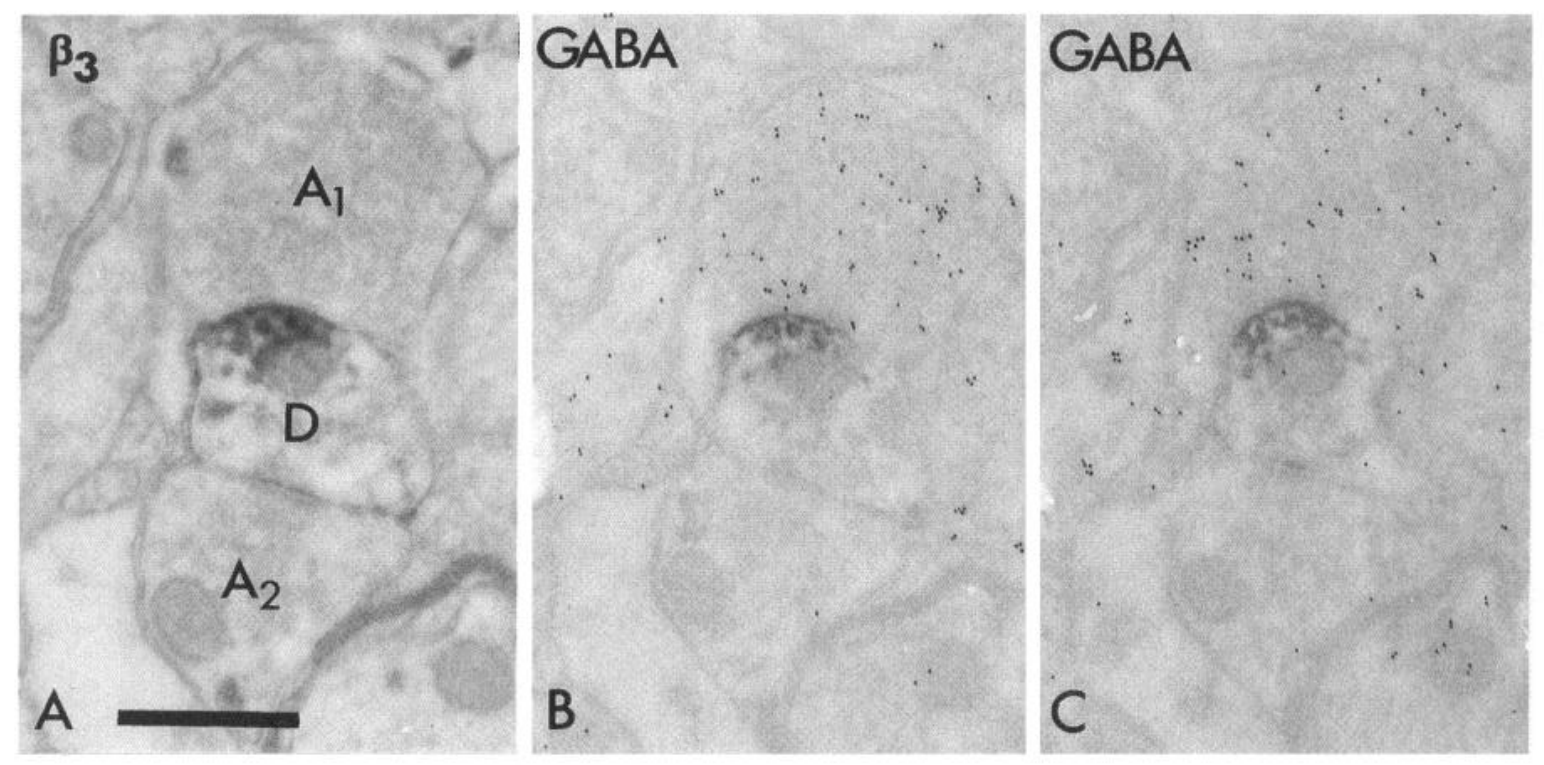

Figure 2. $\mathrm{GAB} \Lambda_{\mathrm{A}}$-receptor $\beta_{3}$ subunit-immunoreactive synapse in lamina III and its relationship to GABA. $A$, Ultrathin section showing a dendrite $(D)$ receiving two synapses from axons $\left(A_{1}\right.$ and $\left.A_{2}\right)$. The synapse formed by $A_{1}$ is $\beta_{3}$-immunoreactive, but there is little spread of reaction product, so the asymmetrical synapse formed by $A_{2}$ is unstained. $B, C$, Equivalent region in two serial sections that were reacted with GABA antiserum by the postembedding method. $A_{1}$ is labeled heavily with gold particles, whereas $\mathrm{A}_{2}$ is not. Scale bar, $0.5 \mu \mathrm{m}$.
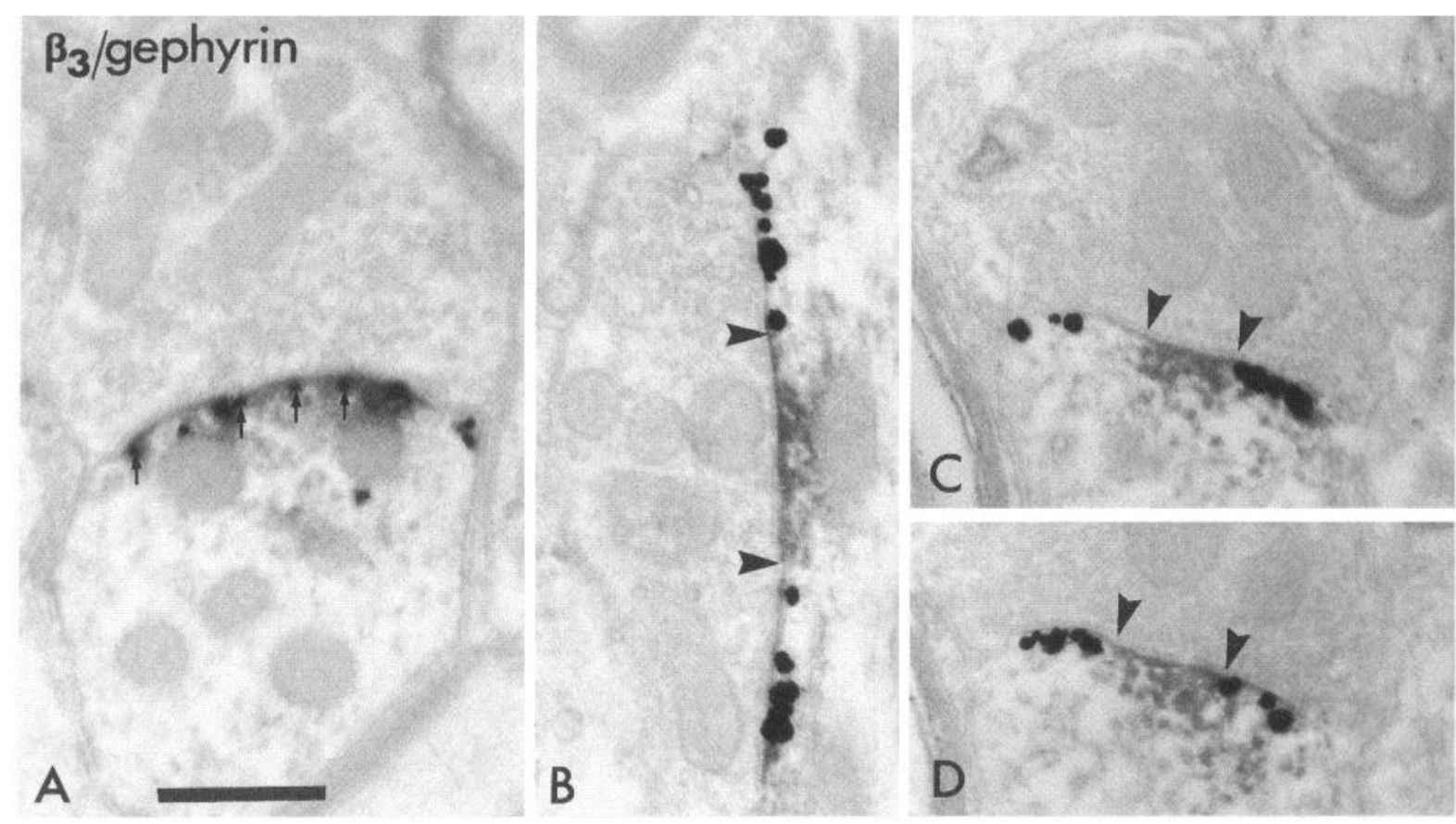

Figure 3. Colocalization of $\mathrm{GABA}_{\mathrm{A}}$-receptor $\beta_{3}$ and gephyrin immunoreactivity at three synapses in the ventral horn. In each case, the gephyrin immunoreactivity is represented by silver particles and the $\beta_{3}$ immunoreactivity is represented by diffuse (DAB) reaction product. $A$, Synapse at which the two types of immunoreactivity are intermingled. Arrows indicate some of the silver particles. $B$, Synapse at which $\beta_{3}$ immunoreactivity (between arrowheads) is located centrally and is surrounded by regions with gephyrin immunoreactivity. $C, D$, Two consecutive ultrathin sections through another synapse with a central region of $\beta_{3}$ immunoreactivity (between arrowheads) and peripheral gephyrin immunoreactivity. Scale bar, $0.5 \mu \mathrm{m}$.

the central part of the active site with silver particles present in clusters on either side (Fig. 3B-D). Because heavy deposition of silver particles could obscure the DAB precipitate, it was not always possible to determine whether particular synapses or areas within synapses were double-labeled.

Because of the likelihood of false-negative results (e.g., attributable to incomplete penetration of antibodies), we did not at- tempt to quantify single- and double-labeled synapses. However, in the deep part of the dorsal horn and in the ventral horn, the density of synapses at which $\mathrm{GABA}_{\mathrm{A}}$-receptor $\beta_{3}$-subunit immunoreactivity was present was much lower than that of gephyrinimmunoreactive synapses, so only a small minority of gephyrinimmunoreactive synapses were double-labeled. Approximately half of the $\beta_{3}$-immunoreactive synapses in these areas were also 

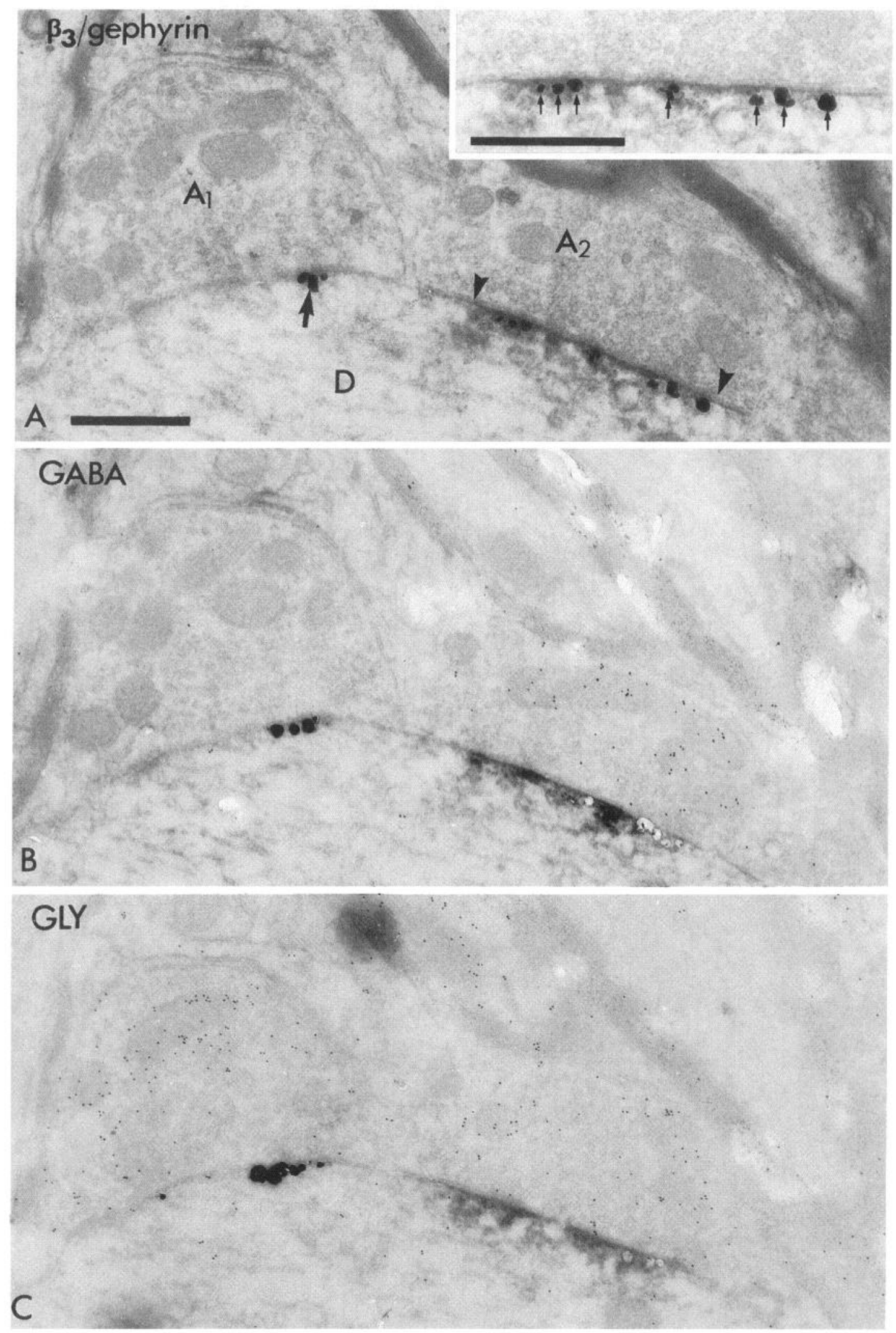

Figure 4. GABA and glycine immunoreactivity at a synapse in the deep dorsal horn that possessed both $\mathrm{GABA}_{\mathrm{A}}$-receptor $\beta_{3}$ and gephyrin immunoreactivity. $A$, Dendrite $(D)$ receives synapses from two axons, $A_{1}$ and $A_{2}$. The synapse involving $A_{1}$ is gephyrin-immunoreactive only (arrow), whereas that involving $A_{2}$ (between arrowheads) has both gephyrin and $\beta_{3}$ immunoreactivity. The inset shows this synapse at higher magnification to reveal the silver particles more clearly (arrows). B, C, The preceding and subsequent ultrathin sections reacted with antiserum to GABA and glycine (GLY), respectively. Axon $A_{2}$ shows both GABA and glycine immunoreactivity, whereas $A_{1}$ is immunoreactive only with glycine antiserum. Scale bar, $0.5 \mu$ m. 

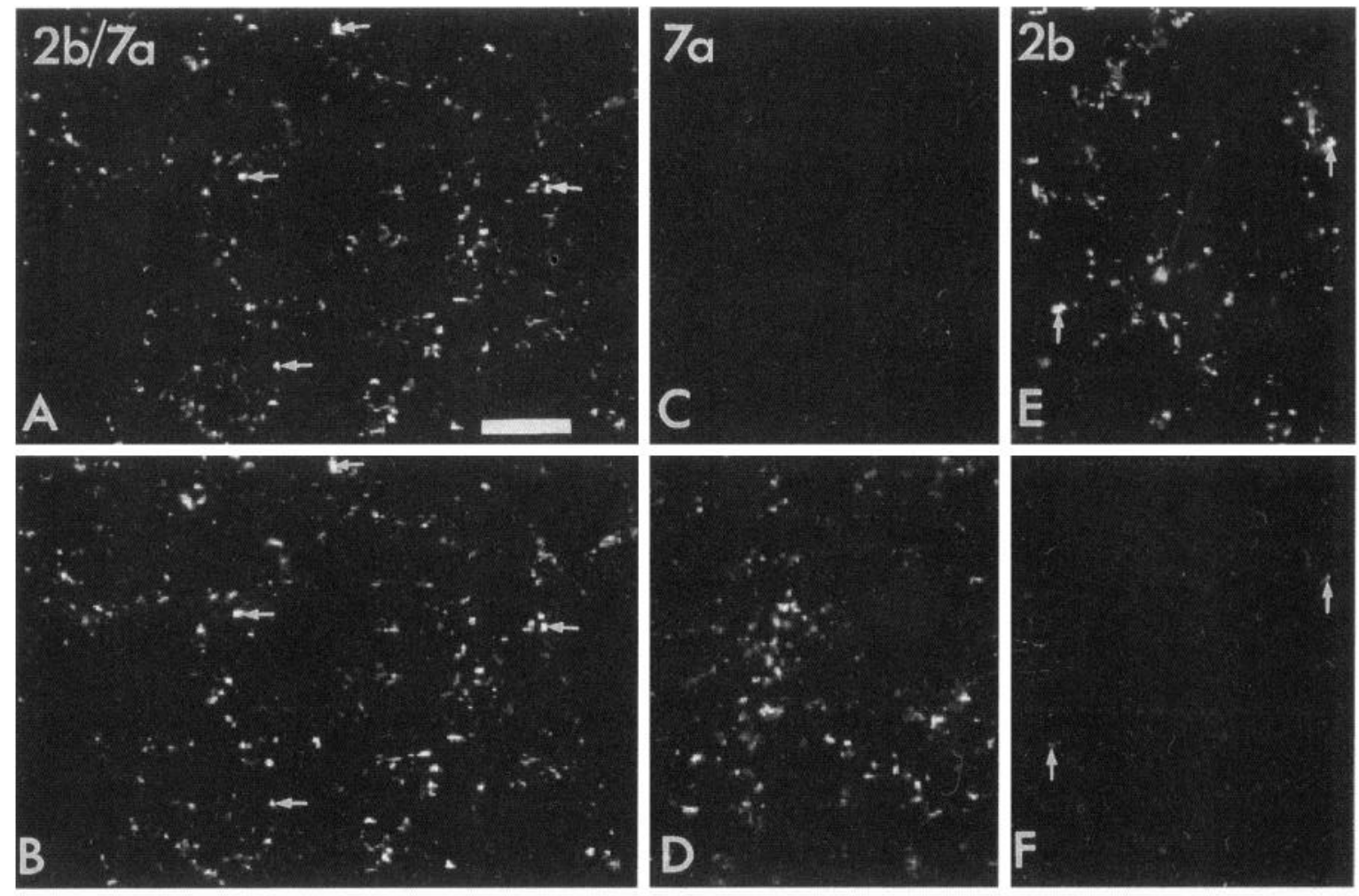

Figure 5. Pairs of confocal images of a section reacted with monoclonal antibodies $2 \mathrm{~b}$ and $7 \mathrm{a}(A, B)$ or control sections reacted only with antibody $7 \mathrm{a}$ $(C, D)$ or $2 \mathrm{~b}(E, F)$. The sections were scanned with the 488 and $586 \mathrm{~nm}$ lines of the laser sequentially to avoid bleed-through fluorescence. In each case, the upper picture $(A, C, E)$ was obtained with the $568 \mathrm{~nm}$ line to reveal lissamine rhodamine (corresponding to immunostaining with antibody $2 \mathrm{~b}$ ), and the lower picture $(B, D, F)$ was obtained with the $488 \mathrm{~nm}$ line for fluorescein (corresponding to antibody $7 \mathrm{a}) . A, B$, Part of lamina IV of the dorsal horn and virtually all of the profiles that are immunoreactive with $7 \mathrm{a}(\mathrm{seen}$ in $B$ ) are also immunoreactive with $2 \mathrm{~b}(A)$. Some of these profiles are indicated with arrows. In a control section, omission of antibody $2 \mathrm{~b}$ caused a complete loss of rhodamine fluorescence $(C)$, whereas strong fluorescein staining was still present $(D)$. This indicates that the rhodamine fluorescence was attributable entirely to antibody $2 \mathrm{~b}$. When antibody $7 \mathrm{a}$ was omitted, very weak residual staining with fluorescein was observed, so the brightest profiles in $E$ are just visible in $F$ (arrows). Scale bar, $10 \mu \mathrm{m}$.

gephyrin-immunoreactive. In the superficial part of the dorsal horn, the DAB reaction product (corresponding to $\beta_{3}$ immunoreactivity) often extended beyond active sites and, therefore, it was more difficult to assess the relative frequency of single- and double-labeled synapses.

To determine whether GABA and glycine were colocalized in axons that formed synapses possessing both $\mathrm{GABA}_{\mathrm{A}}$-receptor $\beta_{3}$ subunit and gephyrin, we selected 40 such synapses and examined them on serial sections reacted with antibodies to GABA and glycine. At 32 of these synapses, the presynaptic axon was enriched significantly with both GABA- and glycine-like immunoreactivity (Fig. 4), and at an additional 7 synapses, the axon was either GABA- or glycine-immunoreactive.

\section{Gephyrin and glycine-receptor $\alpha_{1}$-subunit immunoreactivity}

Because there are differences in the relationship between gephyrin and the glycine-receptor $\alpha_{1}$ subunit in different parts of the nervous system, we tested the reliability of gephyrin as a marker for synapses that possess glycine receptors in the spinal cord. A dual-immunofluorescence method was used to compare the distribution of staining with two monoclonal antibodies: 2b (which recognizes the $\alpha_{1}$ subunit; revealed with lissamine rhodamine) and $7 \mathrm{a}$ (which recognizes gephyrin; revealed with fluorescein). In sections treated with both antibodies, virtually all of the profiles that were stained with fluorescein also were stained with lissamine rhodamine (and vice versa), although the relative intensity of the two types of fluorescence varied from profile to profile (Fig. $5 A, B)$. This pattern of colocalization was found in all laminae of the spinal gray matter and in the lateral and ventral columns of the white matter (where immunoreactive puncta are occasionally present). Omission of antibody $2 \mathrm{~b}$ caused the complete absence of rhodamine fluorescence (Fig. $5 C, D$ ), indicating that this fluorescence was attributable exclusively to glycine-receptor $\alpha_{1}$-subunit immunoreactivity. However, when antibody 7a was omitted, very weak fluorescein staining still was observed (Fig. $5 E, F$ ). This was not attributable to bleed-through fluorescence, because it was observed only when fluorescein-labeled secondary antibody was present and presumably was caused by incomplete blocking of antibody $2 \mathrm{~b}$ before the second immunofluorescent reaction.

\section{DISCUSSION}

\section{GABA $_{A}$ receptors in the spinal cord}

The antibody used here was raised against part of the $\beta_{3}$ subunit that shows little homology with $\beta_{1}$ or $\beta_{2}$ subunits (Ymer et al., 1989). It selectively precipitates recombinant receptors containing $\beta_{3}$ subunit, and we have found that in cerebellum it caused immunostaining only in the granule cell layer (A. J. Todd, R. C. Spike, and W. Sieghart, unpublished observations), which is consistent with the pattern of $\beta_{3}$-subunit expression (Persohn et al., 1992). The immunostaining that we observed, therefore, presumably represents the $\mathrm{GABA}_{\mathrm{A}}$-receptor $\beta_{3}$ subunit. The laminar distribution of $\beta_{3}$ immunoreactivity closely matches that of glu- 
tamic acid decarboxylase (GAD) (McLaughlin et al., 1975) and, because $\beta_{3}$-immunoreactivity was associated with synapses involving GABA-immunoreactive axons, it appears that this subunit is present at GABAergic synapses throughout the spinal cord. Because of limitations of the pre-embedding method, we could not determine whether $\beta_{3}$ subunit was present at all $G \Lambda B \wedge$ ergic synapses.

Early studies with antibodies against various $\mathrm{GABA}_{\mathrm{A}_{\mathrm{A}}}$-receptor subunits (Richards et al., 1987; Somogyi et al., 1989; Zimprich et al., 1991; Fritschy et al., 1992) reported extensive labeling of neurons, with staining of much of the cell membrane; this was taken as evidence of relatively high levels of extrasynaptic GABA $_{A}$ receptor (Somogyi et al., 1989). More recent studies with postembedding immunocytochemistry have indicated that in cerebellum and dentate gyrus, $\alpha_{1}$ and $\beta_{2 / 3}$ subunits are highly concentrated at GABAergic synapses, with extrasynaptic labeling present at lower levels (Nusser et al., 1995a,b). The discrepancy between these results was believed to reflect limited access of antibodies recognizing extracellular epitopes to synaptic clefts with the pre-embedding method, whereas these sites would be accessible on ultrathin sections. It was suggested that, although there are extrasynaptic $\mathrm{GABA}_{\mathrm{A}}$ receptors on these neurons, these receptors are present at much lower concentrations than those found at GABAergic synapses.

The distribution of $\beta$ subunits in rat spinal cord has been reported by Richards et al. (1987) with monoclonal antibody bd17, which recognizes an extracellular epitope on both $\beta_{2}$ and $\beta_{3}$ subunits. They found diffuse granular immunostaining in superficial dorsal horn (as reported here) but extensive staining of cell bodies and dendritic trees of neurons elsewhere in the gray matter. Although the difference hetween the extensive immunostaining of neuronal membranes reported with bd17 and the punctate distribution observed with $\beta_{3}$ antibody in this study could be attributable to the presence of the $\beta_{2}$ subunit, it is unlikely because only a few spinal neurons express this subunit (Persohn et al., 1991, 1992; Wisden et al., 1991; Ma et al., 1993). A more likely explanation is that the $\beta_{3}$ subunit is highly concentrated at GABAergic synapses and, because the antibody we used recognizes an intracellular epitope, it has unrestricted access, causing predominantly synaptic labeling. Although extrasynaptic $\beta_{3}$ subunits are present on many spinal neurons (and are detected by antibody bd17), their density presumably is below the threshold of detection of our immunocytochemical method. The $\beta_{3}$ immunoreactive cell bodies and dendrites that we observed in laminae II-IV apparently are exceptions to this. We have observed similar cell bodies and dendrites in these laminae that were strongly immunostained with antibody bd17 (A. J. Todd and R. C. Spike, unpublished observations). Presumably, these cells have much higher concentrations of extrasynaptic $\mathrm{GABA}_{\mathrm{A}}$-receptor $\beta_{3}$ subunit than other spinal neurons.

There have been few immunocytochemical studies of other $\mathrm{GABA}_{\wedge}$-receptor subunits in rat spinal cord. Bohlhalter et al. (1994) used an antibody directed against an extracellular part of the $\alpha_{1}$ subunit and reported widespread immunostaining of somatic and dendritic membranes of certain neurons, although confocal microscopy revealed the presence of "hotspots" that frequently were apposed to GAD-immunoreactive profiles, suggesting that these hotspots represented accumulations of $\alpha_{1}$ subunit at GABAcrgic synapses. Sur et al. (1995) have reported recently that immunostaining in ventral horn with an antibody recognizing an intracellular epitopc of the $\gamma_{2}$ subunit was restricted primarily to synapses.

\section{Immunocytochemical markers for glycine receptors in the spinal cord}

Various monoclonal antibodies have been used for immunocytochemical detection of glycine receptors (Pfeiffer et al., 1984). Antibody $2 \mathrm{~b}$ is specific for the glycine-receptor $\alpha_{1}$ subunit and, therefore, provides the most reliable way of identifying receptors at presumed glycinergic synapses (Kirsch and Betz, 1993). Unfortunately, immunostaining with antibody $2 \mathbf{b}$ is extremely sensitive to fixation, and we were able to obtain satisfactory immunostaining only by delaying fixation until after incubation in primary antibody. Immunostaining with $\beta_{3}$ antibody was not observed under these conditions and, therefore, we could not compare directly the distribution of glycine-receptor $\alpha_{1}$ subunit with that of $\mathrm{GABA}_{\mathrm{A}}$-receptor $\beta_{3}$ subunit.

Immunostaining with antibody $7 \mathrm{a}$ (which recognizes gephyrin) is resistant to fixation, and this antibody can be used in conditions that allow postembedding detection of GABA and glycine. There is evidence already that gephyrin is restricted to synapses that possess glycine receptors in the spinal cord. The laminar distribution of gephyrin closely matches that of glycine-immunoreactive boutons (van den Pol and Gorcs, 1988; Mitchell et al., 1993), and we have shown that glycinc is cnriched in most axons at gephyrinimmunoreactive synapses (Todd et al., 1995). In addition, Triller et al. (1987) reported a perfect match between immunofluorescence with antibodies $2 b$ and $7 \mathrm{a}$ in ventral horn. Because we found that virtually all gephyrin-immunoreactive structures throughout the spinal cord also were labeled with antibody $2 b$, it appears that in spinal cord gephyrin is restricted to synapses at which glycinereceptor $\alpha_{1}$ subunit is present.

\section{Colocalization of $\mathrm{GABA}_{\mathrm{A}}$ and glycine receptors}

The present results suggest that at certain synapses in spinal cord $\mathrm{GABA}_{\mathrm{A}}$ and glycine receptors are both present on the postsynaptic membrane, whereas GABA and glycine are enriched in the presynaptic axon. They confirm and extend previous reports demonstrating that GAD- or GABA-containing axons can be presynaptic at gephyrin-immunoreactive synapses (Triller et al., 1987; Mitchell et al., 1993) and that hotspots of $\mathrm{GABA}_{\mathrm{A}}$-receptor $\alpha_{1}$-subunit immunoreactivity coexist with gephyrin and are adjacent to GADimmunoreactive profiles (Bohlhalter et al., 1994). However, this apparently is the first study to provide ultrastructural evidence that two classical transmitters and their receptors are present at the same synapse, and it strongly supports the idea that GABA and glycine can act as cotransmitters within the spinal cord.

We frequently observed synapses labeled with only gephyrin or $\mathrm{GABA}_{\mathrm{A}}$-receptor $\beta_{3}$ subunit immunoreactivity, which suggests that some synapses have glycine receptors, some have $\mathrm{CABA}_{\mathrm{A}}$ receptors, and others possess both receptors. This is consistent with pharmacological results showing that inhibition evoked in spinal neurons may be antagonized by strychnine, bicuculline, or both. Studies with antagonists have indicated that there are two components of inhibition of spinal neurons: a fast phase involving glycine receptors and a slower phase mediated by $\mathrm{GABA}_{\mathrm{A}}$ receptors (Game and Lodge, 1975; Baba et al., 1994; Yoshimura and Nishi, 1995), and synapses with different receptor combinations, therefore, presumably will generate IPSPs with different time courses.

Although most of the axons presynaptic at gephyrinimmunoreactive and $\mathrm{GABA}_{\mathrm{A}}$-receptor $\beta_{3}$-immunoreactive synapses were enriched with both GABA and glycine, some were not; and at all but one of these synapses, the axon was either GABA- or glycineimmunorcactive. We also found that a few axons at $\beta_{3}$. immunoreactive synapses were not GABA-immunoreactive, and we 
have reported previously that some axons presynaptic at gephyrinimmunoreactive synapses were not glycine-immunoreactive (Todd et al., 1995). This may indicate that at certain synapses there is a mismatch between transmitter and receptor; however, it is possible that in axons that use both GABA and glycine, one of the transmitters is present at a relatively low concentration that we are unable to detect with our postembedding method.

An unexpected finding in the present study was that when gephyrin and the $\mathrm{GABA}_{\mathrm{A}}$-receptor $\beta_{3}$ subunit both were present at synapses, they often were separated partially or completely (Fig. $3 B-D$ ). This is unlikely to be attributable to suppression of one type of reaction, because the particulate marker was deposited first and should not have impeded binding of $\mathrm{ABC}$ complex or subsequent deposition of DAB. We cannot be certain that the distribution of gephyrin exactly parallels that of the glycine receptor, and it is difficult to assess the spread of the DAB reaction product but, nonetheless, these results suggest that $\mathrm{GABA}_{\mathrm{A}}$ and glycine receptors are concentrated at different parts of the active site at sume synapses at which they are both present. Nusser et al. (1994) have shown that there is separation of ionotropic and metabotropic glutamate receptors at synapses in cerebellum, and the present findings provide additional evidence that the distribution of receptors at synapses may not be homogeneous.

Sassoè-Pognetto et al. (1995) recently demonstrated that in retina gephyrin is colocalized with $\mathrm{GABA}_{\mathrm{A}}$ receptors at synapses that lack glycine receptors. They suggested that gephyrin is involved in aggregation of $\mathrm{GABA}_{\mathrm{A}}$ receptors at these synapses, which is consistent with the finding that GABA $_{A}$ receptors can bind to tubulin (Item and Sieghart, 1994). However, the frequent separation of gephyrin and $\mathrm{GABA}_{\mathrm{A}}$-receptor $\boldsymbol{\beta}_{3}$ subunit that we observed makes it unlikely that gephyrin is involved in anchoring $\mathrm{GABA}_{\mathrm{A}}$ receptors at synapses in spinal cord.

\section{REFERENCES}

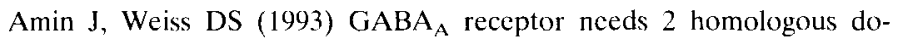
mains of the $\beta$-subunit for activation by GABA but not by pentobarbital. Nature $366: 565-569$.

Baba H, Yoshimura M, Nishi S, Shimoji K (1994) Synaptic responses of substantia gelatinosa neurones to dorsal column stimulation in rat spinal cord in vitro. J Physiol (Lond) 478:87-99.

Bohlhalter S, Möhler H, Fritschy J-M (1994) Inhibitory neurotransmission in rat spinal cord: co-localization of glycine- and $\mathrm{GABA}_{\mathrm{A}}$-receptors at GABAergic synaptic contacts demonstrated by triple immunofluorescence staining. Brain Res 642:59-69.

Chan J, Aoki C, Pickel VM (1990) Optimization of differential immunogold silver and peroxidase labeling with maintenance of ultrastructure in brain sections before plastic embedding. $J$ Neurosci Methods 33:113-127.

Cullheim S, Kellerth J-O (1981) Two kinds of recurrent inhibition of cat spinal $\alpha$-motorneurones as differentiated pharmacologically. J Physiol (Lond) 312:209-224.

Curtis DR, Hosli L, Johnston GAR (1968) A pharmacological study of the depression of spinal neurones by glycine and related amino acids. Exp Brain Res 6:1-18.

Fritschy J-M, Benke D, Mertens S, Oertel WH, Bachi T, Möhler H (1992) Five subtypes of type A $\gamma$-aminobutyric acid receptors identified in neurons by double and triple immunofluorescence staining with subunit-specific antibodies. Proc Natl Acad Sci USA 89:6726-6730.

Game CJA, Lodge D (1975) The pharmacology of the inhibition of dorsal horn neurones by impulses in myelinated cutaneous afferents in the cat. Exp Brain Res 23:75-84.

Holstege JC (1991) Ultrastructural cvidence for GABAergic brain stem projections to spinal motoneurons in the rat. J Neurosci 11:159-167.

Item C, Sieghart W (1994) Binding of $\gamma$-aminobutyric acid A receptors to tubulin. J Neurochem 63:1119-1125.

Kirsch J, Betz H (1993) Widespread expression of gephyrin, a putative glycine receptor-tubulin linker protein, in rat brain. Brain Res $621: 301-310$.
Kirsch J, Langosch D, Prior P, Littaucr UZ, Schmitt B, Betz II (1991) The $93 \mathrm{kDa}$ glycine receptor-associated protein binds to tubulin. J Biol Chem 266:22242-22245.

Kirsch J, Wolters I, Triller A, Betz H (1993) Gephyrin antisense oligonucleotides prevent glycine receptor clustering in spinal neurons. Nature 366:745-748.

Luque JM, Nelson N, Richards JG (1995) Cellular expression of glycine transporter 2 messenger RNA exclusively in rat hindbrain and spinal cord. Neuroscience 64:525-535.

Ma W, Saunders PA, Somogyi R, Poulter MO, Barker JL (1993) Ontogeny of $\mathrm{GABA}_{\mathrm{A}}$ receptor subunit mRNAs in rat spinal cord and dorsal root ganglia. J Comp Neurol 338:337-359.

Malosio M-L, Marqueze-Pouey B, Kuhse J, Betz H (1991) Widespread expression of glycine receptor subunit mRNAs in the adult and developing rat brain. EMBO J 10:2401-2409.

McLaughlin BJ, Barber R, Saito K, Roberts E, Wu JY (1975) Immunocytochemical localization of glutamate decarboxylase in rit spinal cord. J Comp Neurol 164:305-322.

Mitchell K, Spike RC, Todd AJ (1993) An immunocytochemical study of glycine receptor and GABA in laminae I-IIl of rat spinal dorsal horn. J Ncurosci 13:2371-2381.

Mossier B, Tögel M, Fuchs K, Sieghart W (1994) Immunoaffinity purification of $\gamma$-aminobutyric acid A $\left(\mathrm{GABA}_{\mathrm{A}}\right)$ receptors containing $\gamma_{1^{-}}$ subunits. J Biol Chem 269:25777-25782.

Nusser Z, Mulvihill E, Streit P, Somogyi P (1994) Subsynaptic segregation of metabotropic and ionotropic glutamate receptors as revealed by immunogold localization. Neuroscience 61:421-427.

Nusser Z, Roberts JDB, Baude A, Richards JG, Somogyi P (1995a) Relative densities of synaptic and extrasynaptic $G_{A B A}$ receptors on cerebellar granule cells as determined by a quantitative method. $J$ Neurosci 15:2948-2960.

Nusser Z, Roberts JDB, Baude A, Richards JG, Sieghart W, Somogyi P (1995b) Immunocytochemical localization of the $\alpha 1$ and $\beta 2 / 3$ subunits of the $\mathrm{GABA}_{\mathrm{A}}$ receptor in relation to specific GABAergic synapses in the dentate gyrus. Eur J Neurosci 7:630-646.

Örnumg G, Shupliakov O, Ottersen OP, Storm-Mathisen J, Cullheim S (1994) Immunohistochemical evidence for coexistence of glycine and GABA in nerve terminals on cat spinal motorneurones: an ultrastructural study. NeuroReport 5:889-892.

Ottersen OP, Storm-Mathisen J, Somogyi P (1988) Colocalization of glycine-like and CrABA-like immunoreactivities in Golgi cell terminals in the rat cerebellum: a postembedding light and electron microscope study. Brain Res 450:342-353.

Persohn E, Malherbe P, Richards JG (1991) In situ hybridization histochemistry reveals a diversity of GABA receptor subunit mRNAs in neurons of the rat spinal cord and dorsal root ganglia. Neuroscience 42:497-507.

Persohn E, Malherbe P, Richards JG (1992) Comparative molecular neuroanatomy of cloned $\mathrm{GABA}_{\mathrm{A}}$ receptor subunits in the rat CNS. J Comp Neurol 326:193-216.

Pfeiffer G, Simler R, Greenigloh G, Betz H (1984) Monoclonal antibodics and peptide mapping reveal structural similaritics between the subunits of the glycine receptor of the rat spinal cord. Proc Natl Acad Sci USA 81:7224-7227.

Pow DV (1994) Taurine, amino acid transmitters, and related molecules in the retina of the Australian lungfish Neoceratodus forsteri: a lightmicroscopic immunocytochemical and electron-microscopic study. Cell Tissue Res 278:311-326.

Pow DV, Crook DK (1993) Extremely high titre polyclonal antisera against small neurotransmitter molecules: rapid production, characterisation and use in light- and electron-microscopic immunocytochemistry. J Neurosci Methods 48:51-63.

Pow DV, Robinson SK (1994) Glutamate in some retinal neurons is derived solely from glia. Neuroscience 60:355-366.

Richards JG, Schoch P, Häring P, Takacs B, Möhler H (1987) Resolving GABA A benzodiazepine receptors: cellular and subcellular localization in the CNS with monoclonal antibodies. J Neurosci 7:1866-1886.

Rudomin P, Jimenez I, Quevedo J, Solodkin M (1990) Pharmacologic analysis of inhibition produced by last-order intermediate nucleus interneurons mediating nonreciprocal inhibition of motorncurones in cat spinal cord. J Neurophysiol 63:147-160.

Sassoè-Pognetto M, Kirsch J, Grünert U, Greferath U, Fritschy J-M, Möhler H, Betz H, Wässle H (1995) Co-localization of gephyrin and $\mathrm{GABA}_{\mathrm{A}}$ receptor subunits. J Comp Neurol 357:1-14. 
Sato K, Zhang J-H, Saika T, Sato M, Tada K, Tohyama M (1991) Localization of glycine receptor $\alpha_{1}$ subunit mRNA-containing neurons in the rat brain: an analysis using in situ hybridization histochemistry. Neuroscience 43:381-395.

Schneider SP, Fyffe REW (1992) Involvement of GABA and glycine in recurrent inhibition of spinal motoneurons. J Neurophysiol 68:397-406. Sieghart W (1992) GABA receptors: ligand-gated $\mathrm{Cl}^{\circ}$ ion channels modulated by multiple drug-binding sites. Trends Pharmacol Sci $13: 446-450$.

Sigel E, Baur R, Trube G, Möhler H, Malherbe G (1990) The effect of subunit composition of rat brain $\mathrm{GABA}_{\mathrm{A}}$ receptors on channel function. Neuron 5:703-711.

Somogyi P, Takagi H, Richards JG, Möhler H (1989) Subcellular localization of benzodiazepine/GABA $\mathrm{GA}_{\mathrm{A}}$ receptors in the cerebellum of rat, cat, and monkey using monoclonal antibodies. J Neurosci 9:2197-2209.

Sur C, McKernan R, Triller A (1995) Subcellular localization of the GABA $_{\text {A }}$ receptor $\gamma 2$ subunit in the rat spinal cord. Eur J Neurosci 7:1323-1332.

Taal W, Holstege JC (1994) GABA and glycine frequently colocalize in terminals on cat spinal motorneurons. NeuroReport 5:2225-2228.

Todd AJ, Spike RC, Chong D, Neilson M (1995) The relationship between glycine and gephyrin in synapses of the rat spinal cord. Eur J Neurosei $7: 1-11$.
Tögel M, Mossier B, Fuchs K, Sieghart W (1994) $\gamma$-Aminobutyric acid A receptors displaying association of $\gamma_{3}$-subunits with $\beta_{2 / 3}$ and different $\alpha$-subunits exhibit unique pharmacological properties. J Biol Chem 269:12993-12998.

Triller A, Cluzeaud F, Korn H (1987) $\gamma$-Aminobutyric acid-containing synapses can be apposed to glycine receptors at central synapses. J Cell Biol 104:947-956.

van den Pol AN, Gorcs T (1988) Glycine and glycine receptor immunoreactivity in brain and spinal cord. J Neurosci 8:472-492.

Verdoorn TA, Draguhn A, Ymer S, Sccburg PII, Sakmann B (1990) Functional properties of recombinant $\mathrm{GABA}_{\mathrm{A}}$ receptors depend upon subunit composition. Neuron 4:919-928.

Wisden W, Gundlach AL, Barnard EA, Seeburg PH, Hunt SP (1991) Distribution of $\mathrm{GABA}_{\mathrm{A}}$ receptor subunit mRNAs in rat lumbar spinal cord. Mol Brain Res 10:179-183.

Ymer S, Schofield AD, Werner P, Kohler M, Seeburg PH (1989) $\mathrm{GABA}_{\mathrm{A}}$ receptor subunit heterogeneity: functional expression of cloned cDNAs. EMBO J 8:1665-1670.

Yoshimura M, Nishi. S (1995) Primary afferent-evoked glycine- and GABA-mediated IPSPs in substantia gelatinosa neurones in the rat spinal cord in vitro. J Physiol (Lond) 482:29-38.

Zimprich F, Zezula J, Sieghart W, Lassmann H (1991) Immunohistochemical localization of the $\alpha_{1}, \alpha_{2}$, and $\alpha_{3}$ subunits of the $\mathrm{GABA}_{\mathrm{A}}$ receptor in the rat brain. Neurosci Lett 127:125-128. 